\title{
Optimization of thermal stability of structural elements of high-rise buildings to increase their energy efficiency
}

\author{
Botir Giyasov ${ }^{1, *}$, Vyacheslav Semenov ${ }^{1}$, and Irina Giyasova ${ }^{2}$ \\ ${ }^{1}$ Moscow State University of Civil Engineering, Yaroslavskoe shosse, 26, Moscow, 129337, Russia \\ ${ }^{2}$ Tambov State Technical University, Tambov, Russia
}

\begin{abstract}
The problem of improving energy efficiency of modern urban buildings is becoming increasingly important. Urbanization, which contributes to the growth of megacities, causes an increase in the number of modern high-rise buildings and the development of urban infrastructure, resulting in increased energy consumption. When dealing with the energy efficiency of high-rise buildings, it is necessary to take into account such factors as the location, building orientation with respect to the cardinal directions, functional purposes, a three-dimensional and design solutions. Conservation of energy inside high-rise buildings, which contributes to minimum energy consumption in order to create and maintain a comfortable temperature, is one of the urgent tasks. This problem can be solved by thermal insulation of cladding and the use of effective heat-insulating materials to reduce the negative impact of climatic factors on high-rise buildings. Using the example of the Evolution Tower, we analyzed Moscow City high-rise buildings, made calculations and graphs of variation in the temperature and wind speed throughout the height of the building. An increase in wind speed and a decrease in temperature throughout the height of the building create extreme conditions that affect the heat loss of highrise buildings, which must be taken into account in the heat protection of external enclosing structures.
\end{abstract}

\section{Introduction}

The growth of the world's top economies, resulting in an increase in the urban population, contributes to the development of big cities. Currently, about half the world's population lives in cities. The rapidly increasing population density results in the growth in the number of modern multi-storey buildings and high-rise buildings in cities, as well as development of engineering and transport infrastructure at an alarming pace. In big cities with their high concentration of population, a heavy load on transport networks, high energy consumption, the impact on the climate and environment is big enough. In addition, the development of modern high-rise buildings and their increased density change the aerodynamics of the terrain. Big cities have a fairly effective system for heating vertical surfaces of buildings and horizontal surfaces of roofs, sidewalks and roads. In this regard, in some areas of cities, the

\footnotetext{
* Corresponding author: dandyr@mail.ru
} 
density of buildings prevents natural aeration and causes the formation of an "urban heat island" (Figure 1) [2]. Thus, in some areas of modern cities there is a change in climatic parameters, which must be taken into account when designing energy-efficient buildings.
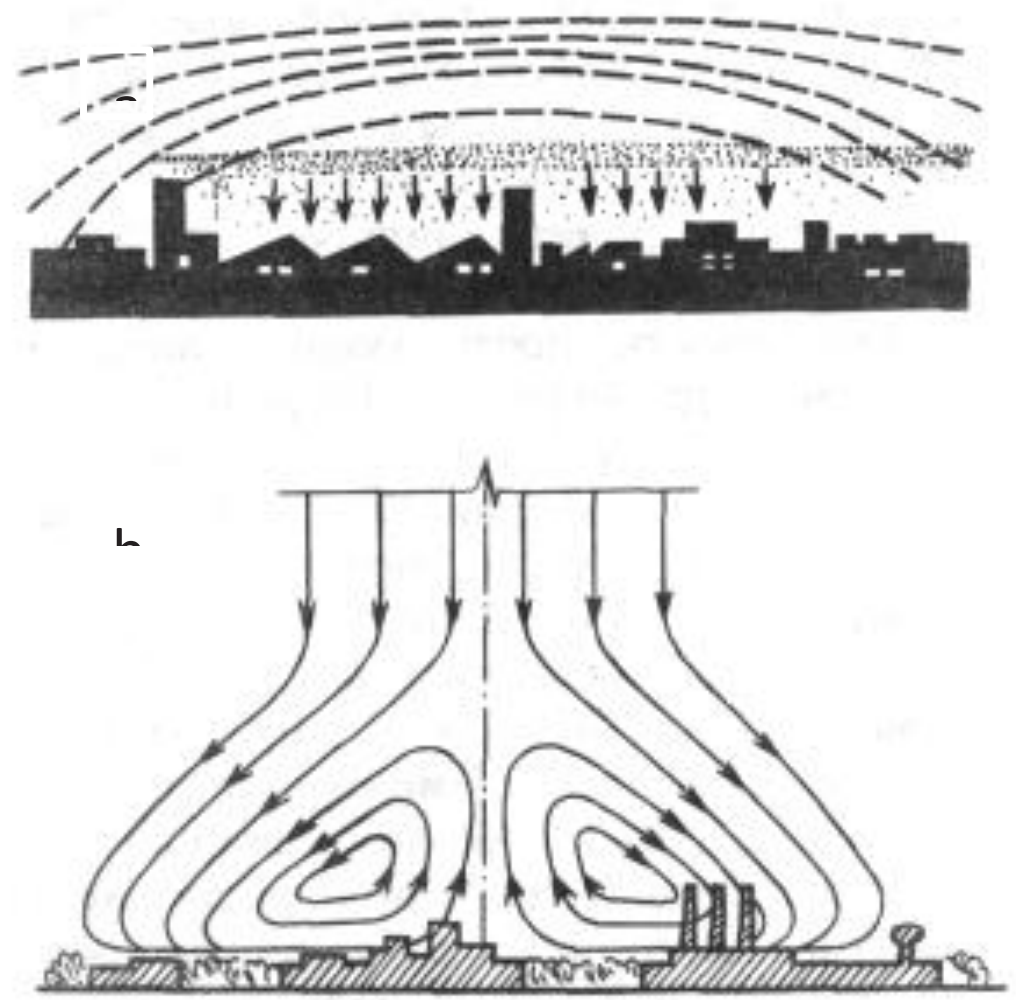

Fig. 1. "Urban heat island" formation: a - dissipation of industrial emissions in the "urban heat island" (deep surface inversion); $\mathrm{b}$ - circulation in the lower atmosphere over the city

\section{Problems}

Currently, an urgent problem is the increased demand for energy resources. Due to the fact that the cost of energy is high, and its reserves are decreasing from year to year, the issue of reducing energy consumption in modern cities is becoming increasingly important.

It is found that energy consumption in construction is greater than the energy consumption of all industries, including factories, plants, metallurgical plants and energy consumed by transport, including cars, trains and ships (Figure 2) [7].

In this regard, the issue of improving the energy efficiency of buildings is becoming increasingly important. 


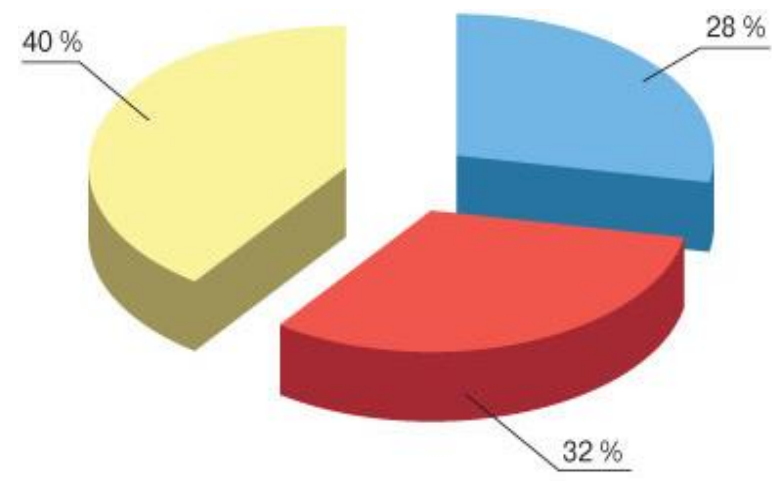

\section{Industry a Transport Construction}

Fig. 2. Consumption of fuel and energy resources in Europe

\section{Results}

Increasing the energy efficiency of buildings means reducing energy consumption while maintaining a comfortable microclimate inside the building. When designing an energy efficient building, several basic architectural and building principles must be observed:

- optimization of geometry, architectural forms and space-planning solutions of the building;

- maximum increase in thermal resistance of enclosing structures;

- ensuring sufficient airtightness of the building structure in relation to the inflow of outside air;

- maximum increase in the level of thermal resistance of translucent enclosing structures.

Buildings, being geometric figures and volumetric polygons, react differently to natural and climatic factors. The thermal stability of buildings directly depends on their shapes and volumes. Obviously, the volumes of thermal losses are affected by the areas of the exterior surfaces of buildings, such as walls, roof and floor.

Studies have shown that the heat loss of a cubic or three-story rectangular and singlestorey elongated building with the same heated area and heated volume is significantly different. Estimating the ratio of the heat loss area of the house (exterior walls, roof and floor under the foundation) to its useful area, it is possible to determine the efficiency of the geometric construction of the building in the aspect of heat losses. Thus, it was found that $100 \%$ is the heat consumption by a cubic three-story building, $117 \%$ is the heat consumption by a three-story rectangular building and $172 \%$ is the heat consumption by a singlestorey building. The results are shown in Figure 3 [3]. Consequently, the lowest level of heat losses can be observed in multi-storey high-rise buildings. 


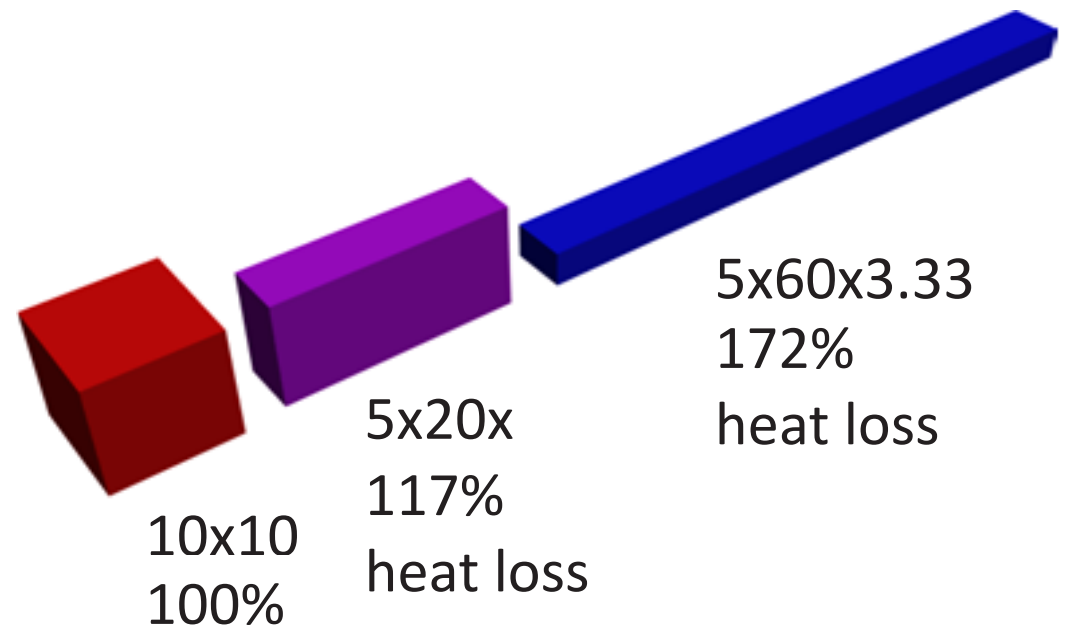

Fig. 3. Diagram of heat consumption of buildings of various architectural shapes

Densely located high-rise urban buildings are exposed to climatic factors, the parameters of which vary depending on the height of the building [8-9]. The analysis and research of the Moscow City International Business Center showed that compactly located towers transformed the wind regime of the area.

The territory of Moscow City Business Center has its local climate, and in some of its streets, high-rise urban buildings have formed a change in microclimatic conditions. According to our studies, there is a change in air temperature and wind speed throughout the height of buildings.

The studies and calculations on the example of Evolution tower have shown changes of external air temperature, atmospheric pressure and wind speed depending on the height of a building.

The change in the outside air temperature and atmospheric pressure throughout the height of the building can be determined by the following formulas [4]:

$$
\begin{gathered}
t_{h}=t_{0}-0.0065 \times h \\
p_{h}=p_{0}\left(1-2.25577 \times 10^{-5} \times h\right)^{5.2559}
\end{gathered}
$$

where $t_{h}, p_{h}$ are temperature, ${ }^{\circ} \mathrm{C}$, and pressure, $\mathrm{Pa}$, respectively, at the height $h, \mathrm{~m}$; $t_{0}, p_{0}$ are temperature, ${ }^{\circ} \mathrm{C}$, and pressure, $\mathrm{Pa}$, respectively, near the ground.

Design climatic parameters are taken from Tables 3.1 and 4.1 for the city of Moscow.

On the basis of the data obtained, the graphs of variation in the outside air temperature throughout the height of the building are plotted (Figure 4). 


\section{a)}

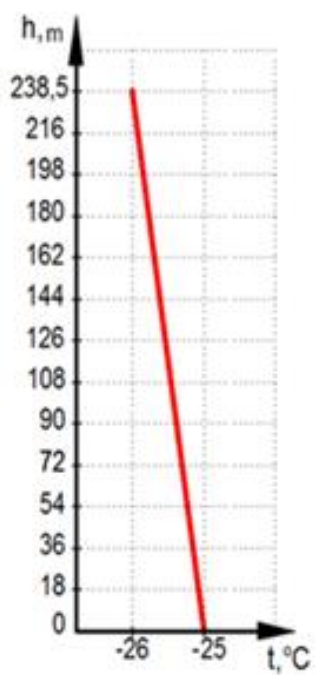

Fig. 4. Variation of outside air temperature along the height of the Evolution Tower in the city of Moscow: a- for the coldest 5-day period; b- for the warm period

Various models are used to estimate the change in wind speed in altitude: the Ekman spiral, the logarithmic law, the power law. These models allow us to estimate the wind speed $V$ at the height $h$, if the wind speed $V_{0}$ at the height $h_{0}$ is known.

The power law of variation of the wind speed with respect to height has the form $[5,6]$ :

$$
V_{h}=V_{0}\left(h / h_{0}\right)^{\alpha}
$$

$V_{0}$ is wind speed, $\mathrm{m} / \mathrm{s}$, at the height $h_{0}, \mathrm{~m}$ (wind speeds are measured at the height of 10-15 $\mathrm{m}$, thus $h_{0}=10-15 \mathrm{~m}$ );

$\alpha$ is an exponent that depends on the type of terrain and is established experimentally; It is recommended to take for centers of big cities $\alpha=0.33$, for suburban sreas $\alpha=0.22$, for open area $\alpha=0.14[6]$.

Based on the calculation results, a graph of the variation in wind speed throughout the height of the building is plotted (Figure 5). 


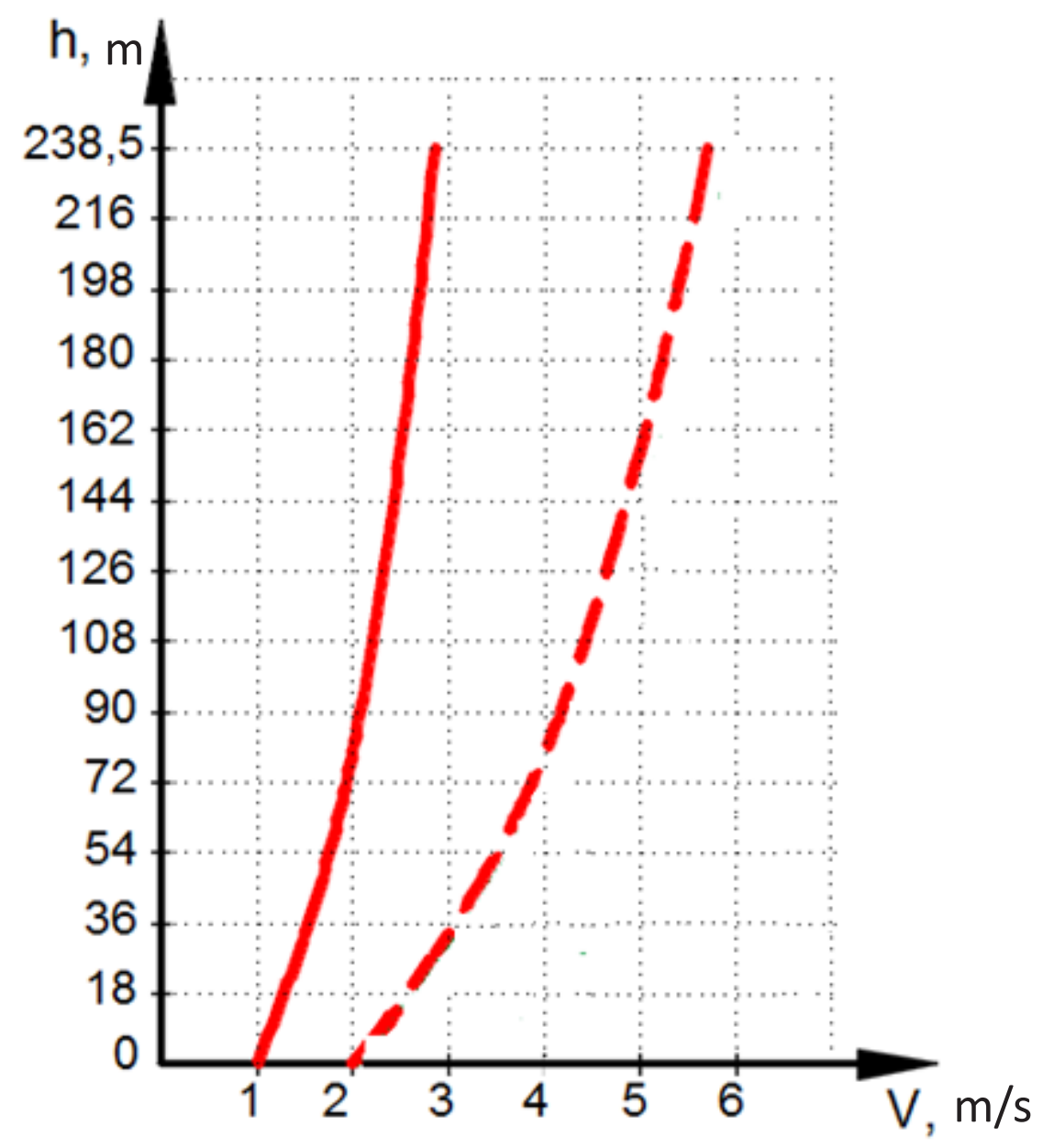

Fig. 5. Variation of the wind speed along the height of the Evolution Tower in the city of Moscow

As can be seen from Figure 5, with an increase in the building height, the wind speed increases and this occurs more intensively in the urban landscape. There is a decrease in the outside air temperature in the summer to $2{ }^{\circ} \mathrm{C}$, in winter - up to $1^{\circ} \mathrm{C}$ and an increase in wind speed up to $2 \mathrm{~m} / \mathrm{s}$ in the warm season, and up to $4 \mathrm{~m} / \mathrm{s}$ in the cold season throughout the height of the building which reaches $238.5 \mathrm{~m}$.

If we consider the cold season, a decrease in the outside air temperature in combination with an increase in wind speed has a significant effect on the heat loss of the building through the external enclosing structures. Consequently, the higher the floor is, the greater the resistance to heat transfer is required for the external enclosing structures, the value of which depends on the material and the insulation of the external enclosing structures and their thickness.

From the data given, it can be seen that the enclosing structures of high-rise buildings are exposed to climatic factors, the parameters of which vary with height. The upper floors of buildings are in the most extreme conditions. In this regard, in order to increase the energy efficiency of high-rise buildings, it is necessary to optimize the heat resistance of the enclosing structures, which implies an increase in the thermal resistance of the external walls and translucent enclosing structures. 
Table 1 shows the data on the dependence of the consumption of thermal energy per year for different structural elements, depending on the resistance to heat transfer and the thickness of insulation.

Table 1. Thermal engineering characteristics of enclosing structures of buildings with different energy consumption

\begin{tabular}{|c|c|c|c|c|}
\hline $\begin{array}{l}\text { Heat } \\
\text { consumption }\end{array}$ & $\begin{array}{c}250-300 \\
\mathrm{~kW} \cdot \mathrm{h} /\left(\mathrm{m}^{2} \bullet \text { year }\right)\end{array}$ & $\begin{array}{c}100-150 \\
\mathrm{~kW} \cdot \mathrm{h} /\left(\mathrm{m}^{2} \bullet \text { year }\right)\end{array}$ & $\begin{array}{c}40-50 \\
\mathrm{~kW} \cdot \mathrm{h} /\left(\mathrm{m}^{2} \cdot \text { year }\right)\end{array}$ & $\begin{array}{c}\leq 15 \\
\mathrm{~kW} \cdot \mathrm{h} /\left(\mathrm{m}^{2} \cdot \text { year }\right)\end{array}$ \\
\hline $\begin{array}{l}\text { Structural } \\
\text { element }\end{array}$ & \multicolumn{4}{|c|}{$\begin{array}{c}\text { resistance to heat transfer } \mathrm{R}, \mathrm{m}^{2} \cdot \mathrm{K} / \mathrm{W} \\
\text { and thickness of insulation, } \mathrm{cm}\end{array}$} \\
\hline $\begin{array}{l}\text { Exterior } \\
\text { wall }\end{array}$ & $0.77 \mathrm{~m}^{2} \cdot \mathrm{K} / \mathrm{W}$ & $2.5 \mathrm{~m}^{2} \cdot \mathrm{K} / \mathrm{W}$ & $5 \mathrm{~m}^{2} \cdot \mathrm{K} / \mathrm{W}$ & $10 \mathrm{~m}^{2} \cdot \mathrm{K} / \mathrm{W}$ \\
\hline Roofing & $1.11 \mathrm{~m}^{2} \cdot \mathrm{K} / \mathrm{W}$ & $4.54 \mathrm{~m}^{2} \cdot \mathrm{K} / \mathrm{W}$ & $6,67 \mathrm{~m}^{2} \cdot \mathrm{K} / \mathrm{W}$ & $10 \mathrm{~m}^{2} \cdot \mathrm{K} / \mathrm{W}$ \\
\hline $\begin{array}{l}\text { Floors on } \\
\text { the ground }\end{array}$ & $1 \mathrm{~m}^{2} \cdot \mathrm{K} / \mathrm{W}$ & $2.5 \mathrm{~m}^{2} \cdot \mathrm{K} / \mathrm{W}$ & $4 \mathrm{~m}^{2} \cdot \mathrm{K} / \mathrm{W}$ & $8.3 \mathrm{~m}^{2} \cdot \mathrm{K} / \mathrm{W}$ \\
\hline Windows & $\begin{array}{l}0.38 \text {; single } \\
\text { glazing }\end{array}$ & $\begin{array}{l}0.58 \text {; double } \\
\text { glazing }\end{array}$ & $\begin{array}{l}0.91 \text {; double } \\
\text { glazing }\end{array}$ & $\begin{array}{l}1.25 \text {; triple } \\
\text { glazing }\end{array}$ \\
\hline
\end{tabular}

Obviously, a reduction in energy consumption can be achieved by increasing the thickness of the structural elements of the enclosing structures. For high-rise buildings, it is advisable to consider structural elements with variable thickness depending on the height of the building in order to achieve an economic effect.

In modern high-rise buildings, light-translucent structures prevail, and the main facade solution involves translucent structures and a ventilated facade. The use of ventilated facades is limited, which is related to the issues of the durability of the bearing structure of the facade system, the fire hazard of the structure, the impact of significant wind loads causing detachment of facade cladding elements. Mineral wool plates are used for thermal insulation, while ceramic granite, fiber cement boards, aluminum composite panels, etc., are used as facings.

\section{Conclusions and recommendations}

The vast majority of skyscrapers around the world are built using translucent facade structures [10]. Such facade structures are quite expensive, they have low resistance to heat transfer and; as a result, the heat loss of the building increases during the winter period and overheating occurs in the summer. Reducing the energy needs of the building to a minimum is possible through the creation of "smart facades", capable of dynamic adaptation to changing climatic conditions. In order to develop the ideal "smart façade" a number of buildings have been created with both single and multi-layered glazing. Double glazing of various designs is used in windows. The most promising application of various functional glasses are multi-layer, energy-saving (low-emission coating), heat-absorbing, electrochromic, with photocatalytic coating, etc. [11]. The use of special glass in double-glazed windows, as well as the filling of an interstitial space with inert gas, significantly increase their operational characteristics and expand the scope of application. Resistance to heat transfer of the most advanced double-glazed windows reaches $1.6 \ldots 2.0 \mathrm{~m}^{2} \cdot \mathrm{K} / \mathrm{W}$. From the energy saving perspective, much attention is paid to the construction of a double trans- 
lucent facade [12-18]. The double facade consists of an outer part with an intermediate space behind it and an inner part. The external part of the facade primarily serves to protect against external climatic influences. In addition, there are openings for the inflow of outside air into the ventilation ducts and the removal of the exhaust air from them, as well as for ventilation of the intermediate space and natural ventilation of the premises. For countries with hot climates, the use of special sun protection elements in the construction of translucent facades is becoming topical [19].

Thus, the improvement of the energy efficiency of high-rise buildings requires:

1. Optimization of the geometric shape of the building in order to reduce the area of external enclosing structures and preserve the usable area;

2. Use of modern thermal insulation materials and optimization of the thickness of structural elements with regard to the variation in outside air temperature and wind speed throughout the height of the building.

3. Application of modern design methods taking into account changing climatic factors to achieve a uniform thermal balance in the functional-spatial system of high-rise buildings.

This work was financially supported by Ministry of Education and Science of the Russian Federation (\#NSh-3492.2018.8).

\section{References}

1. S.P. Hromov, M.A. Petrosjanc, Meteorologija i klimatologija (Nauka, Moscow, 2006)

2. A.S. Bulatova, Mirovaja jekonomika (INFRA-M, Moscow, 2005)

3. A.A. Volkov, B.I. Giyasov, P.D. Chelyshkov, A.V. Sedov, B.S. Strigin, Nauchn.tekhn. , 6, 111, (2014)

4. Je. Simiu, R. Skanlan, Vozdejstvie vetra na zdanija i sooruzhenija (Strojizdat, Moscow, 1984)

5. B.M. Shojhet, Energosb., 7, 62, (2007)

6. A.S. Kubenin, A.N. Fedosova, Nauchn. obozr.,8, 130, (2015)

7. S.Yu. Skripchenkova, Astrah. Vestn. ehkol. obr., 2 (40), 103, (2017)

8. A.A. Magaj, N.V. Dubynin, Vestn. MGSU, 2, 14, (2010)

9. A.A. Magaj, N.V. Dubynin, Vestn. MGSU, 3, 36, (2010)

10. S. Hassanli, K.C.S. Kwok, V. Zhao, Journ. Of Wind Eng. And Ind. Aerod., 175, 292, (2018)

11. N. Ghabra, L. Rodrigues, P. Oldfield, Intern. Journ. Of Low-Carb. Techn., 12(4), 411, (2017)

12. C. Hachem-Vermette, Sol. En., 159, 710, (2018)

13. J.Č. Tovarović,, J. Ivanović-Šekularac, N. Šekularac, Energ. And Build., 152, 653, (2017)

14. E. Generalova, V. Generalov, A. Kuznetsova, Vide. Tehn. Res.-Env., Techn., Resour., 1, 103, (2017)

15. S. Soudian, U. Berardi, Ener. Proc., 132, 249, (2017)

16. R.A. Agathokleous, S.A. Kalogirou, Renew. Energ., 89, 743, (2016)

17. Yu. D. Bibikova, V.V. Burkova, Molod. Vestn. IrGTU, 1, 8, (2016)

18. Y. Sun, Y. Wu, R. Wilson, S. Sun, Build. and Envir., 105, 69, (2016)

19. P.T.H. Ha, IOP Conf. Ser.: Ear. And Envir. Scien., 143, (2018) 